\title{
Effect of calcium on iron absorption in women with marginal iron status
}

\author{
Karima Benkhedda, Mary R. L’Abbé and Kevin A. Cockell* \\ Nutrition Research Division, Bureau of Nutritional Sciences, Food Directorate, Products and Food Branch, Health Canada, \\ Room E321 Banting Research Centre, A.L. 2203E, 251 Sir Frederick Banting Driveway, Ottawa, ON, Canada K1A OK9
}

(Received 3 March 2009 - Revised 3 September 2009 - Accepted 19 September 2009 - First published online 28 October 2009)

We measured non-haem $\mathrm{Fe}$ absorption with and without added $\mathrm{Ca}$ in a short-term feeding study, in thirteen women with marginal Fe status, by the use of a double stable isotope technique. Supplementing $500 \mathrm{mg}$ Ca as calcium carbonate significantly $(P=0.0009)$ reduced Fe absorption from a single meal from $10.2 \%$ (range $2.2-40.6$ ) to $4.8 \%$ (range $0.7-18.9$ ). A significant inverse correlation in the absence $(-0.67, P=0.010)$ and presence $(-0.58, P=0.037)$ of $\mathrm{Ca}$, respectively, was found between Fe absorption and Fe stores measured by serum ferritin (SF). Wide variation in Fe absorption was observed between individuals in the absence and in the presence of $\mathrm{Ca}$, despite pre-selection of participants within a relatively narrow range of iron stores (SF concentrations). Correction of Fe absorption data based on group mean SF was not found to be useful in reducing the inter-individual variability in iron absorption. It appears that selecting a study group with a narrow initial range of Fe stores does not necessarily reduce the inter-individual variability in Fe bioavailability measurements. These results support the hypothesis that body Fe stores, although an important determinant of dietary Fe absorption, are not the main factor that determines Fe absorption under conditions of identical dietary intake in subjects with low Fe stores.

Iron absorption: Calcium inhibition: Low iron stores: Pre-menopausal women

Fe and $\mathrm{Ca}$ are two essential mineral nutrients of particular concern in women's health. Losses of Fe in menstruation and the added needs during pregnancy mean that the RDA for $\mathrm{Fe}$ in adult women are higher than the corresponding value for men ${ }^{(1)}$. Meanwhile, adolescence and early adulthood mark the attainment of peak bone mass, with long-term consequences of increased risk of osteoporosis if $\mathrm{Ca}$ intakes are less than adequate ${ }^{(2)}$. There is evidence that many adolescents and young adult women in North America and elsewhere may have inadequate intakes of $\mathrm{Fe}$ and/or $\mathrm{Ca}^{(1-6)}$. Adding to the complexity of managing optimal mineral nutrition are the known interactions whereby $\mathrm{Ca}$ can inhibit the absorption of dietary $\mathrm{Fe}^{(7-9)}$

Body Fe status can be assessed by a number of biochemical indices including blood $\mathrm{Hb}$ concentration, serum ferritin (SF) concentration, transferrin saturation, serum transferrin receptor concentration and total Fe-binding capacity of serum. It is preferable to use a combination of these indices to improve specificity $^{(10)}$. A recent review of population intervention studies has indicated that $\mathrm{SF}$ and $\mathrm{Hb}$ are the most efficient combination of indicators for monitoring population change in Fe status ${ }^{(11)}$. The level of body Fe stores is reflected by SF, with a typical ratio of $1 \mu \mathrm{g} / \mathrm{l} \mathrm{SF}$ representing approximately $8-10 \mathrm{mg}$ stored $\mathrm{Fe}^{(12)}$. However, $\mathrm{SF}$ is also an acute-phase protein that increases in inflammation and infection; therefore, its association with Fe deficiency needs to be evaluated in combination with another indicator of acute-phase response, such as C-reactive protein $(\mathrm{CRP})^{(13,14)}$.
As human subjects have no physiologically regulated mechanism for $\mathrm{Fe}$ excretion, the content of $\mathrm{Fe}$ in the body is controlled mainly by absorption ${ }^{(15)}$. Dietary Fe absorption is strongly influenced by physiological factors including body Fe status, and by dietary factors (which can be categorised as enhancers or inhibitors) including inhibition by $\mathrm{Ca}^{(1)}$. Inadequate $\mathrm{Fe}$ absorption, if uncorrected, may lead to declining body Fe stores and ultimately to functional consequences including altered erythropoiesis and Fe deficiency anaemia $^{(16)}$.

Common methods for clinical investigation of $\mathrm{Fe}$ absorption may involve single- or multiple-day controlled trials. The relevance of the so-called 'single-meal' studies (which frequently compare absorption from two meals given on consecutive days) has been questioned because of evidence of decreased effect of enhancers or inhibitors on Fe absorption in the context of a complete diet with greater food variety than in the simple meals commonly used in the single-meal trials $^{(17)}$. Nevertheless, single-meal studies remain a useful tool to identify the potential inhibitors or enhancers that affect Fe bioavailability in human subjects ${ }^{(18)}$. Such studies have permitted the identification of numerous determinants of $\mathrm{Fe}$ bioavailability including different chemical forms of Fe salts, aspects of meal composition (i.e. other components interacting with $\mathrm{Fe}$ as inhibitors or enhancers of absorption) and host-related factors such as body Fe status ${ }^{(19)}$.

One interaction that has been subjected to much study is that between $\mathrm{Ca}$ and $\mathrm{Fe}^{(7,8,20-22)}$. Public education to increase 
dietary $\mathrm{Ca}$ intakes, $\mathrm{Ca}$ supplementation and food fortification with $\mathrm{Ca}$ are strategies to decrease the prevalence of $\mathrm{Ca}$ deficiency in young women and their risk of developing osteoporosis later in life. However, there is evidence that absorption of dietary or supplemental non-haem Fe can be compromised by the consumption of $\mathrm{Ca}$ at the same time ${ }^{(21,22)}$. Ca is also the only reported inhibitor for haem $\mathrm{Fe}$ absorption $^{(7)}$. A variable depressing effect (from 0 to $80 \%$ ) of $\mathrm{Ca}$ on $\mathrm{Fe}$ absorption in a dose-related manner has been reported in most single-meal studies and short-term diet interventions in human subjects ${ }^{(23)}$. No inhibition was seen for an amount of $\mathrm{Ca}$ of $<50 \mathrm{mg}$ in a meal $(10 \mathrm{mg}$ native and $40 \mathrm{mg}$ added $\mathrm{Ca}$ ). The inhibition was, however, maximal $(80 \%)$ at a content of $300 \mathrm{mg} \mathrm{Ca}$ per meal. No significant further inhibition was observed when increasing the $\mathrm{Ca}$ content from 300 to $600 \mathrm{mg}^{(7,24)}$. The inhibitory effect of $\mathrm{Ca}$ on absorption of $\mathrm{Fe}$ has been shown to be modified by body Fe status; in one report, $600 \mathrm{mg}$ Ca taken with $18 \mathrm{mg} \mathrm{Fe}$ as $\mathrm{FeSO}_{4}$ had no effect in a group of individuals with low $\mathrm{Fe}$ stores, whereas it caused a decrease of $9 \%$ in $\mathrm{Fe}$ absorption in volunteers with normal $\mathrm{Fe}$ stores $^{(21)}$.

Most of the short- and long-term studies on the effect of $\mathrm{Ca}$ on Fe absorption conducted to date have been performed in groups of individuals with a wide range of Fe status (mostly with adequate $\mathrm{Fe}$ stores), which resulted in high inter-subject variability in $\mathrm{Fe}$ absorption. This variability has been attributed in some cases to dietary factors but mainly to the influence of $\mathrm{Fe}$ status. Correcting for such a difference in $\mathrm{Fe}$ stores to be able to compare dietary absorption in different studies requires adjusting individual absorption values to a common point. This can be done either by using a correction factor relative to an absorption of $40 \%$ for a reference dose, using an average absorption value of $8 \%$ for a standard meal or correcting absorptions using SF values and their known inverse relationship to $\mathrm{Fe}$ absorption ${ }^{(25)}$.

Few data, however, are available for such studies in pre-menopausal women with pre-existing low $\mathrm{Fe}$ stores. It seems important to investigate more in depth the effect of Ca supplementation in this population subgroup, which is at risk for developing Fe deficiency and Fe deficiency anaemia as result of inadequate $\mathrm{Fe}$ intake or bioavailability. Therefore, in the present study, our objective was to evaluate the effect of $\mathrm{Ca}$ on $\mathrm{Fe}$ absorption using singe-meal methodology in a group of woman with marginal Fe status, which represents about $15 \%$ of Canadian women of childbearing age ${ }^{(3)}$. The null hypothesis was that pre-menopausal women with low $\mathrm{Fe}$ stores would show significant inhibition of non-haem $\mathrm{Fe}$ absorption with co-consumption of a typical $\mathrm{Ca}$ supplement tablet. The study also allowed us to evaluate whether pre-selecting a study population within a narrow range of SF would be useful to reduce variability in $\mathrm{Fe}$ absorption measurements in bioavailability studies. This secondary objective was addressed by comparison of results of the present study with observations published in the literature.

\section{Subjects and methods}

Subjects

$\mathrm{Fe}$ absorption with and without added $\mathrm{Ca}$ was measured in thirteen pre-menopausal women with pre-existing marginal
Fe status defined as $\mathrm{Hb}$ between 120 and $160 \mathrm{~g} / \mathrm{l}$, SF between 12 and $24 \mu \mathrm{g} / \mathrm{l}$ and $\mathrm{CRP}<7 \mathrm{mg} / \mathrm{l}$; their mean age was 31.5 years (range 25-38). Potential participants were recruited through public advertising. Persons who responded to the advertisement were given an explanation of the study and were scheduled for screening. Before screening, written informed consent was obtained from each subject. The screening consisted of a brief health questionnaire to detect a history of haematological or gastrointestinal disorders and an assessment of Fe status. Subjects were excluded from the study if they had a history of haematological or gastrointestinal disorders, if their haematological indices fell outside the required range, if they were taking medications that could interfere with haematopoiesis or Fe absorption, if they were taking other supplements and refused to discontinue their use for the duration of the study, if they were pregnant, if they had reached menopause or if they had donated blood during the previous 6 months. The present study was conducted according to the guidelines laid down in the Declaration of Helsinki, and all procedures involving human subjects were approved by the Human Research Ethics Board at Health Canada.

\section{Study design}

Each subject received stable iron isotope-labelled meals on two consecutive mornings. One meal was labelled with $5 \mathrm{mg}$ added $\mathrm{Fe}$ as ${ }^{57} \mathrm{Fe}$, consumed without added $\mathrm{Ca}$, while the other meal was labelled with $5 \mathrm{mg}{ }^{58} \mathrm{Fe}$, consumed with $500 \mathrm{mg}$ added $\mathrm{Ca}$ in the form of $\mathrm{a} \mathrm{CaCO}_{3}$ tablet. Subjects were randomly assigned to begin the study with either the ${ }^{57} \mathrm{Fe}$-labelled breakfast or ${ }^{58} \mathrm{Fe}$-labelled breakfast with the $500 \mathrm{mg} \mathrm{Ca}$ dose. Fourteen days after the second meal, a blood sample was taken from the subjects to measure the $\mathrm{Fe}$ isotopic enrichments for the two labels in comparison with a blood sample taken before the first labelled meal. Fe absorption from the two test meals, with or without $\mathrm{Ca}$, was compared for each subject. The percentage absorption was calculated based on the total blood volume (BV) estimated from the height and weight ${ }^{(26)}$. The red blood cell incorporation of absorbed stable isotopes was assumed to be $80 \%$ in all subjects ${ }^{(27)}$.

\section{Test meals}

Each meal consisted of $2 \times 50 \mathrm{~g}$ bread rolls and $250 \mathrm{~g}$ of deionised water as a beverage. The breakfast was extrinsically labelled with $5 \mathrm{mg}{ }^{57} \mathrm{Fe}$ or ${ }^{58} \mathrm{Fe}$ added as $\mathrm{FeSO}_{4}$ solution by accurate pipetting onto the first roll consumed. The rolls were made with white wheat flour, water, salt, sugar and yeast, and the dough was allowed to rise for $1 \mathrm{~h}$ after mixing the ingredients and again for $30 \mathrm{~min}$ after forming the rolls before baking. The two rolls consumed as a breakfast provided (as analysed by flame atomic absorption spectrophotometry) $3.8 \mathrm{mg} \mathrm{Fe}$ and $19.2 \mathrm{mg} \mathrm{Ca}$, to which $5 \mathrm{mg} \mathrm{Fe}$ stable isotope was added for a total $\mathrm{Fe}$ intake of approximately $8.8 \mathrm{mg}$ per meal.

On day 0 of the study, the subjects arrived at the study centre between 08.00 and 08.30 hours after an overnight fast. The subjects were administered a standard commercial pregnancy test to confirm non-pregnant status, and a blood 
sample was taken for the measurements of $\mathrm{Hb}, \mathrm{SF}, \mathrm{CRP}$ and basal $\mathrm{Fe}$ isotopic ratios. On day 1, the subjects were given the first labelled meal (randomised for order of ${ }^{57} \mathrm{Fe}$ or ${ }^{58} \mathrm{Fe}$ with $\mathrm{Ca}$ ) at breakfast and were asked to refrain from eating or drinking any fluid for the next $3 \mathrm{~h}$. On day 2, subjects were given the second labelled breakfast and were asked to refrain from eating or drinking any fluid for the next $3 \mathrm{~h}$.

\section{Stable isotope labels}

Isotopic labels used in the present study were prepared from $\mathrm{Fe}$ metal isotopically enriched in ${ }^{57} \mathrm{Fe}\left(95.38 \%{ }^{57} \mathrm{Fe}\right)$ and ${ }^{58} \mathrm{Fe}\left(92.8 \%{ }^{58} \mathrm{Fe}\right.$; ISOFLEX USA, San Francisco, CA, USA) by dissolution in $3 \mathrm{M} \mathrm{H}_{2} \mathrm{SO}_{4}$ and dilution to appropriate concentration with ultrapure water (Millipore, Bedford, MA, USA). The exact isotopic composition of ${ }^{57} \mathrm{Fe}$ and ${ }^{58} \mathrm{Fe}$ solutions was measured by multicollector inductively coupled plasma MS. Fe concentrations of the solutions were determined by isotope dilution MS against a commercially available isotopic Fe standard material solution (IRMM014b, EU Institute of Reference Materials, Geel, Belgium). The administered dose was determined by accurate weighing of the first wheat roll of each test meal before and after addition of the stable isotope solution by pipette.

\section{Measurements of iron status}

A total of $15 \mathrm{ml}$ venous blood samples were drawn into EDTA-treated and serum separator tubes at day 0 and $14 \mathrm{~d}$ following the second labelled breakfast. $\mathrm{Hb}, \mathrm{SF}$ and CRP were measured by a commercial medical laboratory service (LifeLabs, Inc., Toronto, ON, Canada) for the assessment of $\mathrm{Fe}$ status. Aliquots of EDTA-treated whole blood from day 0 and day 14 after the second breakfast were stored at $-80^{\circ} \mathrm{C}$ until analysis for $\mathrm{Fe}$ isotopic composition before and after stable isotope incorporation.

\section{Blood sample preparation and isotopic analysis}

To minimise risks of sample contamination during digestion and analysis, only high purity acids and ultrapure water were used throughout the present work. Baseline and stable isotope-enriched blood samples were prepared for isotopic analysis as previously reported ${ }^{(28)}$. Aliquots of $0.5 \mathrm{~g}$ thawed and homogenised venous whole blood were digested in a microwave system using a mixture of $\mathrm{HNO}_{3}$ and $\mathrm{H}_{2} \mathrm{O}_{2}$, and $\mathrm{Fe}$ was separated from the matrix using anion exchange resin AG 1-X8. Total Fe in the samples was determined by flame atomic absorption spectrometry.

The amount of incorporated labels in enriched blood samples was determined from the measurements of ${ }^{57} \mathrm{Fe} /{ }^{56} \mathrm{Fe}$ and ${ }^{58} \mathrm{Fe} /{ }^{56} \mathrm{Fe}$ isotopic ratios before and after administration of the enriched stable isotope labels. All isotopic analysis was carried out with a VG Axiom multicollector inductively coupled plasma MS (VG Elemental, Winsford, Cheshire, UK). An Aridus desolvating sample introduction system (CETAC Technologies, Omaha, NE, USA) with a microconcentric nebulizer $\mathrm{T} 1 \mathrm{H}$ was used to reduce the interference of oxides, hydroxides and molecular ions on $\mathrm{Fe}$ isotopes determination. Instrumental mass bias was corrected by bracketing the samples with a standard reference material IRMM-014b.

\section{Calculation of iron absorption}

The amount of ${ }^{57} \mathrm{Fe}$ and ${ }^{58} \mathrm{Fe}$ isotopic labels present in blood of each subject was determined based on the shift of the isotopic ratios in the blood after red cell incorporation of the absorbed labels. The calculations were based on the principle of isotope dilution and considering the non-monoisotopic character of two isotopic labels and crossover contributions $^{(29)}$. The fractional $\mathrm{Fe}$ absorption was thus determined from the circulating amount of isotopic label assuming $80 \%$ incorporation of the absorbed iron into erythrocytes. The amount of circulating $\mathrm{Fe}$ was calculated based on $\mathrm{BV}$ and $\mathrm{Hb}^{(27)}$ :

$$
\begin{aligned}
\text { Fe content of blood }(\mathrm{mg})= & \text { BV }(\text { litres }) \times \mathrm{Hb}(\mathrm{g} / \mathrm{l}) \\
& \times 3.47(\mathrm{mg} / \mathrm{g}) .
\end{aligned}
$$

BV were calculated using an empirical formula based on height and weight according to Brown et al. ${ }^{(26)}$ :

$$
\begin{aligned}
\mathrm{BV}(\text { litres })= & \left(0.3669 \times \text { height }(\mathrm{m})^{3}\right)+(0.03308 \\
& \times \text { weight }(\mathrm{kg}))+0.1833 .
\end{aligned}
$$

Fe absorption values were expressed as unadjusted data and also as data adjusted to the group geometric mean SF and to a hypothetical SF of $40 \mu \mathrm{g} / \mathrm{l}$. The adjusted data were calculated as follows:

$$
\log \mathrm{A}_{\mathrm{adj}}=\log \mathrm{A}_{\mathrm{obs}}+\log \mathrm{SF}_{\mathrm{s}}-\log \mathrm{SF}_{\mathrm{t}},
$$

where $A_{\text {adj }}$ is the adjusted absorption; $A_{\text {obs }}$ is the observed absorption; $\mathrm{SF}_{\mathrm{s}}$ is the subject's $\mathrm{SF}$; and $\mathrm{SF}_{\mathrm{t}}$ is the target group geometric mean $\mathrm{SF}$ or hypothetical $\mathrm{SF}$ value of $40 \mu \mathrm{g} / \mathrm{l}$.

\section{Statistical analysis}

Because of the skewed distribution of fractional $\mathrm{Fe}$ absorption data, statistical analysis was performed on log-transformed data and the results were reconverted by antilogarithm to recover the original units. Paired $t$ test was used to compare $\mathrm{Fe}$ absorption in the presence or absence of $\mathrm{Ca}$. The relationship between Fe stores (as SF) and $\mathrm{Fe}$ absorption was examined using a linear regression model. A significance level of $P<0.05$ was used for all statistical tests.

\section{Results}

\section{Subject characteristics and iron status}

Serum CRP concentrations were $<7 \mathrm{mg} / \mathrm{l}$ for all subjects (data not shown), within the normal reference range used by the commercial medical laboratory doing the clinical blood analyses for the present study. When screened for inclusion in the study, the subjects had mean $\mathrm{Hb}$ of 132.8 (SD 6.4) g/l (range 120-143) and geometric mean SF of $17 \cdot 8 \mu \mathrm{g} / \mathrm{l}$ (range 13-24; Table 1). Because of scheduling logistics with the study participants, there was an average lag time of 8 weeks (range 1-19 weeks) between screening and initiation of the study. On day 0 , some of the participants showed a higher $\mathrm{SF}$ compared to their values from the screening test, with 
Table 1. Characteristics of young adult women participating in the present study at time of screening and at day 0 of the study

(Mean values and standard deviations with their ranges)

\begin{tabular}{lclc}
\hline Index & Mean & SD & Range \\
\hline Age (years) & 30.9 & 5 & $20-38$ \\
Weight $(\mathrm{kg})$ & 64.7 & 7.5 & $54-76$ \\
Height $(\mathrm{m})$ & 1.68 & 0.05 & $1.6-1.8$ \\
BMl $\left(\mathrm{kg} / \mathrm{m}^{2}\right)$ & 22.87 & 2.40 & $19.45-27.90$ \\
Serum ferritin $\left(\mu \mathrm{g} / \mathrm{l}^{\star}\right.$ & & & \\
$\quad$ Screening & 17.8 & 3.8 & $13-24$ \\
$\quad$ Day 0 & 18.4 & 9.5 & $9-35$ \\
$\mathrm{Hb}(\mathrm{g} / \mathrm{l})$ & & & \\
$\quad$ Screening & 132.8 & 6.4 & $120-143$ \\
$\quad$ Day 0 & 134.8 & 9.8 & $112-149$ \\
\hline
\end{tabular}

* Geometric mean, $n 13$.

CRP values still $<7 \mathrm{mg} / \mathrm{l}$. The mean $\mathrm{Hb}$ for the group was increased slightly to 134.8 (SD 9.8) $\mathrm{g} / \mathrm{l}$, and their geometric mean SF increased to $18.4 \mu \mathrm{g} / \mathrm{l}$.

\section{Effect of calcium on iron absorption}

Fractional $\mathrm{Fe}$ absorption was calculated as the ratio of the amount of ${ }^{57} \mathrm{Fe}$ and ${ }^{58} \mathrm{Fe}$ incorporated into red blood cells $14 \mathrm{~d}$ after the second test meal to the ingested amount of either stable isotope label, and is presented as geometric mean and as the ratio of absorption measured with $v$. without added $\mathrm{Ca}$ (Table 2). Fractional $\mathrm{Fe}$ absorption ranged from $2 \cdot 2$ to $40.6 \%$ and from 0.7 to $18.9 \%$ in the absence and presence of $500 \mathrm{mg} \mathrm{Ca}$ as the carbonate, respectively. The ratio of $\mathrm{Fe}$ absorption from the test meal containing $\mathrm{Ca}$ to that without (i.e. $+\mathrm{Ca} /-\mathrm{Ca}$ ) was calculated as an expression of the effect of $\mathrm{Ca}$ on $\mathrm{Fe}$ absorption. The ratio varied from 0.16 to 1.08. The addition of $\mathrm{CaCO}_{3}$ supplement to the breakfast meal reduced group geometric mean absorption of the

Table 2. Fractional iron absorption values for thirteen pre-menopausal women with pre-existing marginal iron status, measured in the presence and absence of $500 \mathrm{mg}$ calcium (as $\mathrm{CaCO}_{3}$ )

\begin{tabular}{|c|c|c|c|c|}
\hline \multirow[b]{2}{*}{ Subject } & \multirow{2}{*}{$\begin{array}{c}\text { Fe status at day } 0 \\
(\mathrm{SF}(\mu \mathrm{g} / \mathrm{l}))\end{array}$} & \multicolumn{2}{|c|}{$\begin{array}{l}\text { Fe absorption } \\
\text { (\% dose) }\end{array}$} & \multirow{2}{*}{$\begin{array}{c}\text { Absorption ratio } \\
\quad+\mathrm{Ca} /-\mathrm{Ca}\end{array}$} \\
\hline & & $-\mathrm{Ca}$ & $+\mathrm{Ca}$ & \\
\hline 1 & 34 & 3.4 & 0.7 & 0.19 \\
\hline 2 & 26 & $4 \cdot 2$ & $4 \cdot 0$ & 0.96 \\
\hline 3 & 15 & 14.5 & $2 \cdot 4$ & 0.16 \\
\hline 4 & 27 & $18 \cdot 8$ & 14.0 & 0.74 \\
\hline 5 & 27 & $12 \cdot 7$ & $8 \cdot 3$ & 0.65 \\
\hline 6 & 28 & $3 \cdot 3$ & 0.7 & 0.20 \\
\hline 7 & 9 & $15 \cdot 8$ & $17 \cdot 0$ & 1.08 \\
\hline 8 & 12 & $40 \cdot 6$ & 12.9 & 0.32 \\
\hline 9 & 23 & $12 \cdot 8$ & $10 \cdot 2$ & 0.80 \\
\hline 10 & 10 & $14 \cdot 2$ & $7 \cdot 3$ & 0.51 \\
\hline 11 & 11 & 36.9 & 18.9 & 0.51 \\
\hline 12 & 11 & $8 \cdot 0$ & 3.7 & 0.46 \\
\hline 13 & 35 & $2 \cdot 2$ & $1 \cdot 3$ & 0.58 \\
\hline Mean* & $18 \cdot 4$ & $10 \cdot 2$ & $4 \cdot 8$ & 0.47 \\
\hline$+1 \mathrm{SD}$ & $30 \cdot 6$ & 25.5 & $15 \cdot 6$ & 0.88 \\
\hline$-1 \mathrm{SD}$ & $11 \cdot 1$ & $4 \cdot 1$ & 1.5 & 0.25 \\
\hline
\end{tabular}

SF, serum ferritin.

${ }^{*}$ Geometric mean, $n 13$. co-consumed $\mathrm{Fe}$ from 10.2 to $4.8 \%$, a significant $(P=0.0009) 53 \%$ decrease (ranging from 0 to $84 \%$ ).

In an attempt to reduce inter-individual variations in $\mathrm{Fe}$ absorption, adjusted individual iron absorption was calculated by applying a correction equation using the group mean $\mathrm{SF}$ $(18.4 \mu \mathrm{g} / \mathrm{l})$ or using a hypothetical SF value of $40 \mu \mathrm{g} / \mathrm{l}$ (Table 3). There was no significant difference $(P=0.999)$ between the uncorrected mean values for ${ }^{57} \mathrm{Fe}$ absorption (without added $\mathrm{Ca}$ ) and those corrected for the group mean value of $\mathrm{SF}$. The $\mathrm{CV}$, calculated as percentage relative standard deviation using the log-transformed data, was reduced from 39 to $29 \%$ and from 74 to $63 \%$ in the absence and presence of $\mathrm{Ca}$, respectively. It has been common practice in the studies on Fe absorption to correct for inter-individual variation using a hypothetical SF of $40 \mu \mathrm{g} / \mathrm{l}$. In the present work, such correction, for ${ }^{57} \mathrm{Fe}$ absorption, resulted in significant reduction $(P=0.00013)$ of the mean fractional absorption value from 10.2 to $4.7 \%$ with no improvement in the $\mathrm{CV}$ (44.6\% v. $39 \%$ for non-corrected values).

\section{Correlation of iron status with iron absorption}

Within the relatively narrow range of SF investigated in the present study $(9-35 \mu \mathrm{g} / \mathrm{l})$, there was a trend of increased $\mathrm{Fe}$ absorption for lower concentrations of $\mathrm{SF}$ in either the presence or absence of added Ca (Fig. 1). Significant inverse correlation was found in the absence $(r-0.67, P=0.01)$ and presence $(r-0.58, P=0.04)$ of $\mathrm{Ca}$, respectively, between $\mathrm{SF}$ (Fe stores) and $\mathrm{Fe}$ absorbed.

\section{Discussion}

The present study, conducted in a group of pre-menopausal adult women with marginal body $\mathrm{Fe}$ stores, defined as SF (at screening) in the range $12-24 \mu \mathrm{g} / \mathrm{l}$ with normal $\mathrm{Hb}$ levels, showed a mean fractional non-haem Fe absorption

Table 3. Iron absorption values for thirteen pre-menopausal women with pre-existing marginal iron status, arithmetically corrected to group geometric mean serum ferritin (SF) and to a hypothetical SF of $40 \mu \mathrm{g} / \mathrm{l}$

\begin{tabular}{|c|c|c|c|c|}
\hline \multirow[b]{3}{*}{ Subject } & \multicolumn{4}{|c|}{ Fe absorption (\%) corrected to } \\
\hline & \multicolumn{2}{|c|}{$\begin{array}{l}\text { Group mean SF } \\
(18.4 \mu \mathrm{g} / \mathrm{l})\end{array}$} & \multicolumn{2}{|c|}{$\begin{array}{l}\text { Hypothetical SF } \\
\quad(40 \mu \mathrm{g} / \mathrm{l})\end{array}$} \\
\hline & $-\mathrm{Ca}$ & $+\mathrm{Ca}$ & $-\mathrm{Ca}$ & $+\mathrm{Ca}$ \\
\hline 1 & $6 \cdot 3$ & $1 \cdot 2$ & 2.9 & 0.6 \\
\hline 2 & $5 \cdot 9$ & $5 \cdot 6$ & $2 \cdot 7$ & 2.6 \\
\hline 3 & $11 \cdot 7$ & 1.9 & $5 \cdot 4$ & 0.9 \\
\hline 4 & $27 \cdot 3$ & $20 \cdot 3$ & $12 \cdot 7$ & $9 \cdot 4$ \\
\hline 5 & $18 \cdot 5$ & $12 \cdot 0$ & $8 \cdot 6$ & 5.6 \\
\hline 6 & $5 \cdot 0$ & $1 \cdot 0$ & $2 \cdot 3$ & 0.5 \\
\hline 7 & $7 \cdot 7$ & $8 \cdot 3$ & 3.6 & 3.8 \\
\hline 8 & $26 \cdot 2$ & $8 \cdot 3$ & $12 \cdot 2$ & 3.9 \\
\hline 9 & $15 \cdot 9$ & $12 \cdot 6$ & $7 \cdot 4$ & 5.9 \\
\hline 10 & $7 \cdot 6$ & 3.9 & 3.5 & 1.8 \\
\hline 11 & 21.9 & $11 \cdot 2$ & $10 \cdot 1$ & $5 \cdot 2$ \\
\hline 12 & $5 \cdot 2$ & $2 \cdot 4$ & $2 \cdot 4$ & $1 \cdot 1$ \\
\hline 13 & $4 \cdot 1$ & $2 \cdot 4$ & 1.9 & $1 \cdot 1$ \\
\hline Mean* & $10 \cdot 2$ & $4 \cdot 8$ & $4 \cdot 7$ & $2 \cdot 3$ \\
\hline$+1 \mathrm{SD}$ & $19 \cdot 7$ & $13 \cdot 0$ & $9 \cdot 3$ & 5.9 \\
\hline$-1 S D$ & $5 \cdot 3$ & $1 \cdot 8$ & $2 \cdot 3$ & 0.9 \\
\hline
\end{tabular}

${ }^{*}$ Geometric mean, $n 13$. 


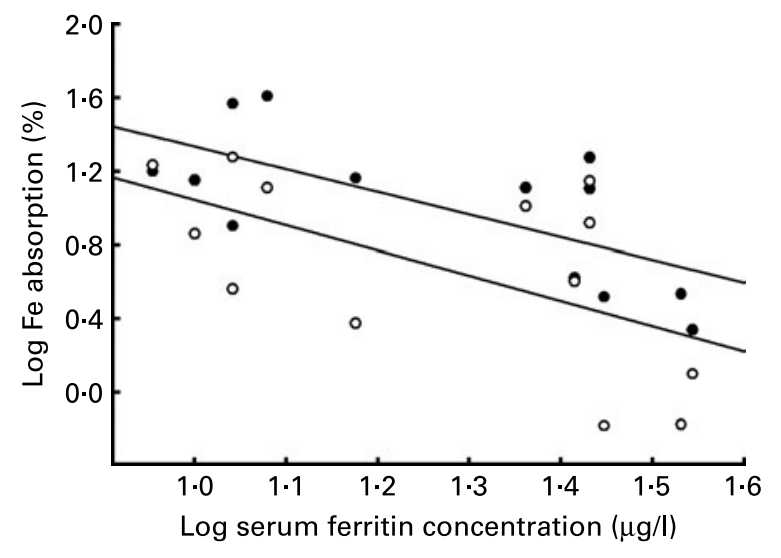

Fig. 1. Relationship between log serum ferritin and log absorption of iron in a single-meal study. The regression line for iron absorption without calcium $(\bullet)$ was $y=-1.2317 x+2.5661\left(r^{2} 0.4597\right)$ and for iron absorption with calcium (o) was $y=-1.3617 x+2.4035\left(r^{2} 0.3382\right)$.

from a simple bread meal to be $10 \cdot 2 \%$. The results of the present study confirm the inhibitory effect of $500 \mathrm{mg} \mathrm{Ca}$ on non-haem Fe absorption in single-meal studies, with a magnitude of inhibition in the present study of $53 \%$ (range $0-84 \%$ ). The range of inhibition found in the present study is comparable to the reductions of $0-80 \%$ in $\mathrm{Fe}$ absorption reported in other studies in human subjects at doses between 165 and $300 \mathrm{mg} \mathrm{Ca}^{(7,20,21,30)}$. It is interesting to note that in the present study, two subjects with SF values of 9 and $26 \mu \mathrm{g} / \mathrm{l}$ showed no effect of the added $\mathrm{Ca}$ with absorption ratios of 0.96 and $1 \cdot 08$, respectively. Similar lack of inhibitory effect of $\mathrm{Ca}$ on non-haem $\mathrm{Fe}$ absorption in some individuals in a short-term test has been noted previously ${ }^{(21)}$.

For some participants, a shift in SF values to higher values on day 0 of the study was observed compared to the time of initial screening. Up to several weeks had elapsed between screening and the start of the study (day 0). An attempt was made to control for the contribution of possible inflammation on the elevation of SF values by the concurrent measurement of CRP, for which the values were reported to be normal (ranging from $<3$ to up to $7 \mathrm{mg} / \mathrm{l}$ ) for the participants included in the study. The variation in Fe status between screening day and study start day may have been attributable to biological intra-individual variability, which has been estimated to be about $20 \%$ in females ${ }^{(31)}$. Moreover, it has been reported that even a very mild infection might influence the level of $\mathrm{SF}^{(32)}$, which might also have contributed to the shift of SF concentrations to slightly higher values. Despite the observed changes in SF between the time of screening and the start of the study, the participating women had low iron stores (SF range $9-35 \mu \mathrm{g} / \mathrm{l}$ ) at day 0 .

In comparison to radioisotope tracer studies, the use of stable isotopes often necessitates the administration of relatively large amounts of isotope to yield a measurable change in isotope ratios. Human studies of $\mathrm{Fe}$ absorption commonly use several milligrams of iron stable isotope in a dose $\mathrm{e}^{(27,29,33,34)}$. However, stable isotopes do not involve the same ethical constraints as radioisotopes for use in human subjects $^{(35)}$. The $5 \mathrm{mg}$ stable isotope doses used in the present study had been shown in a pilot study in our laboratory to be amply adequate for quantification of enrichment following absorption from the simple wheat roll meal matrix ${ }^{(28)}$.
In the present study, we have focused on pre-menopausal women with low $\mathrm{Fe}$ stores for investigation of the effect of $\mathrm{Ca}$ on $\mathrm{Fe}$ absorption, with one objective being to minimise inter-individual variations in Fe absorption caused by variability in body Fe stores. The results obtained in the present study show large inter-individual variations in $\mathrm{Fe}$ absorption, with $(0.7-18.9 \%)$ and without added $\mathrm{Ca}(2.2-40.6 \% \mathrm{Fe}$ absorption), despite the selection of participants within a relatively narrow range of initial SF values. In a study by Cook et al. ${ }^{(21)}$, ten young men with SF $19-171 \mu \mathrm{g} / \mathrm{l}$ had Fe absorption measurements ranging from $1.6-34.0 \%$ from a standard hamburger meal. In an earlier study ${ }^{(36)}$, twenty-two men and women, heterozygous relatives of haemochromatosis patients with SF ranging from 7-221 $\mu \mathrm{g} / \mathrm{l}$, had non-haem Fe absorption measurements ranging from $1.4-23.3 \%$ from a standard hamburger meal.

Investigation of individuals within a wide range of body $\mathrm{Fe}$ stores, as found in other studies, has generally employed correction of $\mathrm{Fe}$ absorption using a reference dose, or correction equations involving $\mathrm{SF}$, to be able to compare absorption values obtained in different studies under different experimental conditions. We found, in the present study on pre-menopausal women with low Fe stores, that such calculations did not improve the interpretation of results. A similar conclusion was reached by Davidsson et al. ${ }^{(37)}$ in earlier studies on erythrocyte incorporation of $\mathrm{Fe}$ by infants.

There is a little information in the literature on the inhibitory effect of $\mathrm{Ca}$ specifically in pre-menopausal women with low $\mathrm{Fe}$ stores. Cook et al. ${ }^{(21)}$ reported on the effect of different $\mathrm{Ca}$ salts on $\mathrm{Fe}$ absorption, taken with or without food, in volunteers with low or normal Fe stores. In a group of eight women and one man with low Fe stores (mean SF $24 \mu \mathrm{g} / \mathrm{l})$, they reported a slight increase in $\mathrm{Fe}$ absorption from 18 to $21.5 \%$ of a dose of $18 \mathrm{mg} \mathrm{Fe}$ as $\mathrm{FeSO}_{4}$ in the absence or presence of $600 \mathrm{mg} \mathrm{Ca}$ as $\mathrm{CaCO}_{3}$ without food (given with water only). The amount of $\mathrm{Fe}$ given was much larger than the amount of $\mathrm{Fe}$ in our test breakfast, and two of their subjects had SF values of 73 and $75 \mu \mathrm{g} / \mathrm{l}$, so the results may not be directly comparable to the present work. A similar study in the same report ${ }^{(21)}$, where the effect of $600 \mathrm{mg} \mathrm{Ca}$ (as carbonate) was tested in the context of a hamburger meal, revealed an average $44 \%$ inhibition (range $10-65 \%$ ).

There are relatively few reports relating body Fe stores to non-haem $\mathrm{Fe}$ absorption in single-meal studies. A highly significant inverse correlation between SF and non-haem $\mathrm{Fe}$ absorption was reported for forty-seven normal control subjects (with SF values ranging from $<10$ to $>200 \mu \mathrm{g} / \mathrm{l}$ ) in a study of the effects of haemochromatosis ${ }^{(36)}$. Roughead et al. ${ }^{(38)}$ have found that non-haem Fe absorption was inversely correlated with SF in either the presence or absence of added $\mathrm{Ca}$, in either low- or high-Fe bioavailability diets. SF values for male and female participants in that study ranged widely $(4-219 \mu \mathrm{g} / \mathrm{l})$, in contrast to the relatively narrow range of $\mathrm{SF}$ in the present work. In a study on Fe absorption from soyabean in women with low body $\mathrm{Fe}$ stores ${ }^{(39)}$, there was a significant inverse correlation between SF and absorption of $\mathrm{Fe}$ from plant (soyabean) ferritin. Over half of the women in that study were $\mathrm{Fe}$ deficient, having SF $<10 \mu \mathrm{g} / \mathrm{l}$, which contrasts to the marginal, but not frankly deficient, iron stores of women in the present work. 
In a study focusing on women with a smaller range of SF $(4-73 \mu \mathrm{g} / \mathrm{l})$ and incorporating a radioactive $\mathrm{Fe}$ tracer into all meals over a 2-d period, inverse correlation of $\mathrm{Fe}$ absorption with SF was found only in the context of a highbioavailability diet, but not a low-bioavailability diet ${ }^{(40)}$. Similar correlation had been found in an earlier study in men, where the range in SF concentrations had been $22-336 \mu \mathrm{g} / \mathrm{l}$, although the pattern reversed (i.e. became significant with the low- bioavailability diet, but not the high-bioavailability diet) after 10 weeks $^{(41)}$. Subjects in the present study were consuming their habitual diets, apart from the simple test breakfasts used in the $\mathrm{Fe}$ absorption test (which did not contain important amounts of enhancers or inhibitors apart from $\mathrm{Ca}$ ).

It has been demonstrated in several studies on dietary $\mathrm{Fe}$ bioavailability, within a wide range of body $\mathrm{Fe}$ status (for example SF in the range $8-242 \mu \mathrm{g} / \mathrm{l})^{(25)}$, that Fe status rather than dietary bioavailability is the major factor determining the extent of $\mathrm{Fe}$ absorption from the diet. However, the regulation of body $\mathrm{Fe}$ stores is complex and still not completely understood $^{(42)}$. Recent work has shown a strong correlation between concentrations of SF and plasma hepcidin, a protein involved in the regulation of Fe absorption ${ }^{(33)}$. Circulating hepcidin has been shown to be inversely correlated with iron absorption in men ${ }^{(33)}$ and women ${ }^{(34)}$.

The size of body Fe stores is one of the main factors believed to modulate the rate of intestinal $\mathrm{Fe}$ absorption, such that $\mathrm{Fe}$ absorption increases several fold in states of $\mathrm{Fe}$ deficiency and decreases in $\mathrm{Fe}$ overload $^{(43)}$. However, in the present study, there was still a significant variation in $\mathrm{Fe}$ absorption despite the relatively narrow range of body $\mathrm{Fe}$ stores of the subjects. The present findings on the relationship between $\mathrm{Fe}$ stores and Fe absorption seem to suggest that Fe stores may not be the main physiological factor determining $\mathrm{Fe}$ (or more particularly non-haem $\mathrm{Fe}$ ) absorption in subjects with low body $\mathrm{Fe}$ stores. Interestingly, our observations are supported by the report of Reddy et al. ${ }^{(18)}$, who have analysed by multiple regression the results from twenty-five radioisotopically labelled meals in human subjects. They concluded that dietary factors such as inhibitors and enhancers accounted for $16 \%$ of variability in Fe absorption, and body $\mathrm{Fe}$ stores (as indicated by SF) accounted for $32 \%$ of variability, while about half of the variation was due to unexplained factors. The large variations observed in menstrual $\mathrm{Fe}$ losses in women of reproductive age are known to affect body Fe stores ${ }^{(44)}$. It would be interesting to investigate whether there might be some more direct impact of this variable on $\mathrm{Fe}$ absorption. Further studies including hepcidin and other proteins involved in $\mathrm{Fe}$ metabolism may also prove fruitful.

In conclusion, we have confirmed the null hypothesis that pre-menopausal women with low Fe stores show significant inhibition of non-haem Fe absorption with co-consumption of a typical $\mathrm{Ca}$ supplement tablet. Pre-selection of a study group with a narrow initial range of SF values did not appear to reduce inter-individual variability in measured $\mathrm{Fe}$ absorption. The results of the present study and reported observations from previous studies suggest that additional physiologic or genetic factors, besides the levels of body $\mathrm{Fe}$ stores and type of diet consumed, have strong influences on $\mathrm{Fe}$ absorption in individuals with similar body Fe stores.

\section{Acknowledgements}

Financial support for the present work was obtained through internal funding of Health Canada. The authors declare no conflict of interest regarding the present work, financial or otherwise. The study described in the present paper was planned by K. A. C. and M. R. L. K. B. was responsible for day-to-day conduct of the study. K. B. and K. A. C. wrote the manuscript, with editorial input by M. R. L.

\section{References}

1. Institute of Medicine (2001) Iron. In Dietary Reference Intakes for Vitamin A, Vitamin K, Arsenic, Boron, Chromium, Copper, Iodine, Iron, Manganese, Molybdenum, Nickel, Silicon, Vanadium, and Zinc, pp. 290-393. Washington, DC: National Academy Press.

2. Institute of Medicine (1998) Calcium. In Dietary Reference Intakes for Calcium, Phosphorus, Magnesium, Vitamin D and Fluoride, pp. 71-145. Washington, DC: National Academy Press.

3. Cooper MJ, Cockell KA \& L'Abbé MR (2006) The iron status of Canadian adolescents and adults: current knowledge and practical implications. Can J Dietet Pract Res 67, 130-138.

4. Ma J, Johns RA \& Stafford RS (2007) Americans are not meeting current calcium recommendations. Am J Clin Nutr 85, $1361-1366$.

5. Aggett P (1995) Iron and women in the reproductive years. In Iron: Nutritional and Physiological Significance, pp. 110-118 [The British Nutrition Foundation Iron Task Force, editor]. London: Chapman \& Hall.

6. Theobald HE (2005) Dietary calcium and health. Nutr Bull 30, 237-277.

7. Hallberg L, Brune M, Erlandsson M, et al. (1991) Calcium: effect of different amounts on non-heme- and heme- iron absorption in humans. Am J Clin Nutr 53, 112-119.

8. Gleerup A, Rossander-Hulthen L, Gramatkovski E, et al. (1995) Iron absorption from the whole diet: comparison of the effect of two different distributions of daily calcium intake. Am J Clin Nutr 61, 97-104.

9. Hallberg L (1998) Does calcium interfere with iron absorption? Am J Clin Nutr 68, 3-4.

10. Looker AC, Gunter EW \& Johnson CL (1995) Methods to assess iron status in various NHANES surveys. Nutr Rev 53, 246-254.

11. Mei Z, Cogswell ME, Parvanta I, et al. (2005) Hemoglobin and ferritin are currently the most efficient indicators of population response to iron interventions: an analysis of nine randomized controlled trials. J Nutr 135, 1974-1980.

12. Cook JD (1999) Defining optimal body iron. Proc Nutr Soc 58, 489-495.

13. Cook JD, Flowers CH \& Skikne BS (2003) The quantitative assessment of body iron. Blood 101, 3359-3364.

14. Gibson RS (2005) Assessment of iron status. In Principles of Nutritional Assessment, 2nd ed., pp. 443-477. New York: Oxford University Press.

15. McCance RA \& Widdowson EM (1937) Absorption and excretion of iron. Lancet 230, 680-684.

16. Zimmermann MB \& Hurrell RF (2007) Nutritional iron deficiency. Lancet 370, 511-520.

17. Cook JD \& Reddy MB (2001) Effect of ascorbic acid intake on non-heme iron absorption from a complete diet. Am J Clin Nutr 73, 93-98.

18. Reddy MB, Hurrell RF \& Cook JD (2000) Estimation of nonheme iron bioavailability from meal compositon. Am J Clin Nutr 71, 937-943. 
19. Singh M, Sanderson P, Hurrell RF, et al. (2006) Iron bioavailability. UK Food standards agency workshop report. $\mathrm{Br} \mathrm{J}$ Nutr 96, 985-990.

20. Deehr MS, Dallal GE, Smith KT, et al. (1990) Effect of different calcium sources on iron absorption in postmenopausal women. Am J Clin Nutr 51, 95-99.

21. Cook JD, Dassenko AS \& Whittaker P (1991) Calcium supplementation; effect on iron absorption. Am J Clin Nutr 53, 106-111.

22. Minihane AM \& Fairweather-Tait SJ (1998) Effect of calcium supplementation on daily non-heme iron absorption and longterm iron status. Am J Clin Nutr 68, 96-102.

23. Bendich A (2001) Calcium supplementation and iron status of females. Nutrition 17, 46-51.

24. Hallberg L, Rossander-Hultén L, Brune M, et al. (1992) Calcium and iron absorption: mechanism of action and nutritional importance. Eur J Clin Nutr 46, 317-327.

25. Cook JD, Dassenko SA \& Lynch SR (1991) Assessment of the role of non-heme iron availability in iron balance. Am J Clin Nutr 54, 717-722.

26. Brown E, Hopper J Jr, Hodges JL Jr, et al. (1962) Red cell, plasma and blood volume in healthy women measured by radiochromium cell labelling and hematocrit. J Clin Invest 41, 2182-2190.

27. Kastenmayer P, Davidsson L, Gallan P, et al. (1994) A double stable isotope technique for measuring iron absorption in infants. Br J Nutr 71, 411-424.

28. Benkhedda K, Chen H, Dabeka R, et al. (2008) Isotope ratio measurements of iron in blood samples by multi-collector ICP-MS to support nutritional investigations in humans. Biol Trace Elem Res 122, 179-192.

29. Walczyk T, Davidsson L, Zavaleta N, et al. (1997) Stable isotope labels as a tool to determine the iron absorption by Peruvian school children from a breakfast meal. Fresenius J Anal Chem 359, 445-449.

30. Sokoll LJ \& Dawson-Hughes B (1992) Calcium supplementation and plasma ferritin concentrations in premenopausal women. Am J Clin Nutr 56, 1045-1048.

31. Cooper MJ \& Zlotkin SH (1996) Day-to-day variation of transferrin receptor and ferritin in healthy men and women. Am J Clin Nutr 64, 738-742.

32. Hulthén L, Lindstedt G, Lundberg PA, et al. (1998) Effect of mild infection on serum ferritin concentration - clinical and epidemiological implications. Eur J Clin Nutr 52, 376-379.
33. Roe MA, Collings R, Dainty JR, et al. (2009) Plasma hepcidin concentrations significantly predict interindividual variation in iron absorption in healthy men. Am J Clin Nutr 89, $1088-1091$

34. Young MF, Glahn RP, Ariza-Nieto M, et al. (2009) Serum hepcidin is significantly associated with iron absorption from food and supplemental sources in healthy young women. Am J Clin Nutr 89, 533-538.

35. Fairweather-Tait SJ, Fox TE, Harvey LJ, et al. (2001) Methods for analysis of trace-element absorption. In Advances in Isotope Methods for the Analysis of Trace Elements in Man, pp. 59-80 [N Lowe and M Jackson, editors]. Boca Raton, FL: CRC Press.

36. Lynch SR, Skikne BS \& Cook JD (1989) Food iron absorption in idiopathic hemochromatosis. Blood 74, 2187-2193.

37. Davidsson L, Ziegler EE, Kastenmayer P, et al. (2000) Erythrocyte incorporation of iron by infants: iron bioavailability from a low-iron infant formula and an evaluation of the usefulness of correcting erythrocyte incorporation values, using a reference dose or plasma ferritin concentrations. $\mathrm{Br} J$ Nutr 84, 847-853.

38. Roughead ZK, Zito CA \& Hunt JR (2005) Inhibitory effect of dietary calcium on the initial intake and subsequent retention of heme and nonheme iron in humans: comparisons using an intestinal lavage method. Am J Clin Nutr 82, 589-597.

39. Murray-Kolb LE, Welch R, Theil EC, et al. (2003) Woman with low iron stores absorb iron from soybeans. Am J Clin Nutr 77, $180-184$.

40. Hunt JR (2003) High-, but not low-bioavailability diets enable substantial control of women's iron absorption in relation to body iron stores, with minimal adaptation within several weeks. Am J Clin Nutr 78, 1168-1177.

41. Hunt JR \& Roughead ZK (2000) Adaptation of iron absorption in men consuming diets with high or low iron bioavailabaility. Am J Clin Nutr 71, 94-102.

42. Beard JL, Dawson H \& Piñero DJ (1996) Iron metabolism: a comprehensive review. Nutr Rev 54, 295-317.

43. Testa U (2002) Proteins of Iron Metabolism. Boca Raton, FL: CRC Press.

44. Harvey LJ, Armah CN, Dainty JR, et al. (2005) Impact of menstrual blood loss and diet on iron deficiency among women in the UK. Br J Nutr 94, 557-564. 